Rodoljub M. Etinski, Ph.D., Full Professor

University of Novi Sad

Faculty of Law Novi Sad

R.Etinski@pf.uns.ac.rs

\title{
MEANS OF INTERPRETATION AND THEIR INTERRELATIONSHIP
}

\begin{abstract}
Authentic and some supplementary means of international treaties have been determined by Articles 31 and 32 of the Vienna Convention on the Law of Treaties. During the process of codification in the International Law Commission determination of these means was not a subject-matter of differences among members of the Commission or among States, but determination of an order of priority among them was. At the end the Commission took the view that all authentic means have to be applied and that their mutual interaction would lead to legally relevant interpretation. Today international judicial bodies do not follow that view. They select some of available authentic and supplementary means and give them different weight. Such interpretative practice may serve aequum et bonum, but may be turned into interpretative ad-hocism. Causes and consequences should be investigated. Discovering certain regularity in respect to factors determining selection and the weight of various means might increase legal certainty and predictability, what would be good for the rule of law.
\end{abstract}

Key words: interpretation, international treaties

\section{INTRODUCTION ${ }^{1}$}

Differences in interpretation of international treaties are not unexpected events. All arbitrary clauses in international treaties transfer powers to international courts and tribunals to resolve disputes on interpretation and application of these treaties. Article 36 ( 2 a) of the Statute of the International Court of Justice empowers the parties unilaterally to accept the jurisdiction of the Court in all

${ }^{1}$ This research has been done in the framework of the research project "Legal Tradition and New Legal Challenges" financed by the Faculty of Law of the Novi Sad University. 
legal disputes concerning interpretation of the treaties. Statistics on international disputes would most probably show remarkable percent of disputes on interpretation in total percent of disputes. It is not a rare occasion that judges of an international court are divided in the interpretation.

Basic rules on interpretation of international treaties have been codified in Articles $31-33$ of the 1969 Vienna Convention on the Law of Treaties (hereinafter: the VCLT) and they have been transformed in general customary rules. Differences in respect to rules on interpretation were expressed in scholarly writings, in the International Law Commission (hereinafter: the ILC) during its work on codification and among States. Judicial practice has not been fully coherent in respect to these rules. Due to this reason, the codified rules came as a result of consensus based in compromise. They diminished previously existed differences, but did not precisely answer all relevant questions. It is important that the relationship among various means of interpretation has not been precisely and clearly regulated. In last years the ILC has continued to consider subsequent agreements, as authentic means and subsequent practice as authentic and supplementary means of interpretation in the light of interpretative practice of various judicial bodies which did not exist or did not produce practice at time when the ILC was drafting the VCLT. The First report on subsequent agreements and subsequent practice in relation to treaty interpretation by Georg Nolte, Special Rapporteur of the ILC, showed that there is no uniform application of codified rules in interpretative practices of various international courts and tribunals. Differences exist especially in respect to the weight that various judicial bodies attribute to various means of interpretation. It would be important to explore causes and consequences of these differences.

This article begins with considering the relationship of discretion and legal certainty as two legal values connected with the interpretation. After an attempt to determine purposes and means of interpretation, it will try to present as briefly as possible the genesis of codification and various views of members of the ILC and of States which were reconciled in codified rules. It will finish by referring to differences in interpretative practices of various international judicial bodies and by conclusion on underlying importance of further investigation of the causes and consequences of these differences.

\section{DISCRETION AND LEGAL CERTAINTY}

Sir H. Waldock, the Special Rapporteur on the Law of Treaties, opened discussion about codification of rules of interpretation in the ILC by considering reasons pro and contra codification. He did not have a problem to find a lot of principles, maxims and methods of interpretation, but he faced an incoherency of 
jurisprudence regarding interpretation and observed that the jurisprudence of international tribunals displays various approaches to interpretation - textual, subjective and teleological. ${ }^{2}$ More importantly, he observed that recourse to many of principles and methods of interpretation is discretionary rather that obligatory and interpretation of documents is to some extent an art, not an exact science. ${ }^{3}$ This view was not shared completely by many members of the ILC and the final outcome of their work did not confirm that recourse to most means of interpretation was discretionary rather that obligatory. But, that does not mean that Articles $31-33$ do not leave any discretion to an interpreter. Recently, Linderfalk published an article entitled "Is Treaty Interpretation an Art or Science? International Law and Rational Decision Making". ${ }^{4}$ He argued that Articles 31-33 of the VCLT left some discretion to interpreter concerning the extension of a means of interpretation, the relationships between a means and an interpreted treaty or the priority of the rules of interpretation. ${ }^{5}$ If discretion serves to aequum et bonum, it is not the enemy of the law. Commenting the proposed provisions on interpretation in the Draft of the ILC, one Government stated the Commission encroached as little as possible on the freedom of the interpreter. ${ }^{6}$ It seems that the Government thought that the freedom of an interpreter is something wishful.

On the other hand, discretion might be a source of uncertainty and arbitrariness; it might be the enemy of legal security and the rule of law. Sir H. Waldock, the Special Rapporteur invoked as an argument pro codification that the fundamental principle of law of international treaties - pacta sunt servanda - requires "interpretation of treaties without arbitrariness and according to law." Preference to discretion or legal certainty influences the approach to interpretation, to our readiness to follow teleological, subjective or textual approach.

2 The Third Report on the Law of Treaties, Sir Humphrey Waldock, Special Rapporteur of the International Law Commission, Doc A/CN.4/167 and Add. 1-3, The Yearbook of the International Law Commission, 2/1964, 54, para 7.

${ }^{3}$ Ibid., para 6. In its Report on the work of its eighteenth session the International Law Commission repeated that recourse to many of these principles is discretionary rather than obligatory and the interpretation of documents is to some extent an art, not an exact science. Report of the International Law Commission on the work of its eighteenth session, Geneva, 4 May - 19 July 1966, The Yearbook of the International Law Commission, 2/1966, 218

${ }^{4}$ Ulf Linderfalk, Is Treaty Interpretation an Art or Science? International Law and Rational Decision Making, The European Journal of International Law, 1/2015, 169.

${ }^{5}$ Ibid., 175

${ }^{6}$ Portugal: "The Commission endeavoured to encroach as little as possible on the freedom of the interpreter, but without refusing him a number of guiding principles drawn from the practice of international tribunals and from a common fund of theoretical writings." Report of the International Law Commission on the work of its eighteenth session, Geneva, 4 May - 19 July 1966, The Yearbook of the International Law Commission, 2/1966, 336

${ }^{7}$ The Third Report on the Law of Treaties, op. cit., para 8. 


\section{PURPOSE AND MEANS OF INTERPRETATION}

Determination of the purpose of interpretation has been, most probably, imported from Roman civil law. The purpose of interpretation is establishing the intention of the parties to a treaty, expressed through the words of a text and through other indications. The Special Rapporteur, the ILC and the States shared such understanding of the purpose. In fact, the outcome of the interpretation is to determine the meaning of the provision of a treaty by establishing the intention of the parties to the treaty in question.

The interpretation is an inherent element of the application of a treaty. Each application of a treaty includes its interpretation. Beside, the interpretation touches the issue of creation of international law and the issue of the relationship between rules of international law. The consent, as essential element in the creation of law, is important also for establishing the relevance of evidence of intention of the parties. The connection between the conclusion of a treaty and its interpretation was observed by the ILC which remarked that: "... the establishment of some measure of agreement in regard to the basic rules of interpretation is important not only for the application but also for the drafting of treaties." ${ }^{8}$ Officials, who are drafting a treaty, should have in mind the rules according to which it will be interpreted.

Rules of international law in force among the parties shall be taken into consideration in the process of interpretation of a treaty. On the one side, they may contribute to ascertaining the meaning of a treaty provision. On the other side, if a treaty rule and other rules of international law govern the same situation, it will be necessary to establish the relationship between them, which might be the one of conflict or the one of harmony. Additionally, it will be also necessary to consider the issues of priority between rules or co-effects of them etc. Sometimes, in practice it is difficult to establish a clear border between the interpretation of a treaty provision by reference to other rules of international law and determination of effects of the treaty provision in relationship with other rules of international law.

Means of interpretation denote admissible evidence of intention of the parties as well as ways of ascertaining the intention of the parties. Other terms have been used to express the same meanings, such as approaches, methods, elements, principles, maxims, rules or guidelines, and they are not necessarily identical in their scope. Principle of good faith would rather be the method than the means of interpretation. It does not refer to any evidence of the intention of the parties, but to the requirement to believe to some evidence. Textual, intentional and functional

\footnotetext{
${ }^{8}$ Report of the International Law Commission on the work of its eighteenth session, Geneva, 4 May - 19 July 1966, The Yearbook of the International Law Commission, 2/1966, 219, para 5
} 
approaches to interpretation were differentiated. ${ }^{9}$ Also, distinction was made between extensive and restrictive interpretation. Each of them includes more methods or means. Some of them, like the guidelines, may imply a sub-obligatory level.

In his Third Report Sir H. Waldock spoke about authentic and subsidiary means of interpretation. ${ }^{10}$ The terms "auxiliary,"11 "sources of interpretation of the second degree"12 and further means ${ }^{13}$ were also used to denote means which at the end were labeled as supplementary means. The Special Rapporteur did not define the meaning of authentic means of interpretation. In the comment of the general rule, which comprehends authentic means, the ILC stated: "The elements of interpretation in article 27 all relate to the agreement between the parties at the time when or after it received authentic expression in the text." ${ }^{14}$ The agreement between the parties, albeit tacit, makes distinctive feature of authentic means.

\section{GENESIS OF CODIFICATION}

There were three versions of the drafted provisions on interpretation. The first version appeared in Third Report of the Special Rapporteur, Sir. H. Waldock. The rules on interpretation were contained in Articles 70 to 75 of the Draft. ${ }^{15}$ Article 70, under title "General rules" was composed of three paragraphs related to authentic means of interpretation, supplementary means and the special meaning of the term, respectively. Article 71, entitled as "Application of the General rules" included two paragraphs. The first explained the meaning of the context of a treaty and the second referred to other evidence and indication of the intentions of the parties, beyond the text and context of a treaty, such as the preparatory work, the circumstances surrounding the conclusion of a treaty and the subsequent practice. Article 72 dealt with the effective interpretation of the terms. It expressed the maxim ut res magis valeat quam pereat. Article 73 regulated the effects of legal development after the conclusion of a treaty to its interpretation and application. Articles 74 and 75 were dedicated to particularities of interpretation of treaties drawn in two or more linguistic versions. These provisions were located

\footnotetext{
${ }^{9}$ United Nations Conference on the Law of Treaties, Second session, Vienna, 9 April - 22 May 1969, Official Records, Summary records of the plenary meetings and of the meetings of the Committee of the Whole, United Nations, New York, 1970, 58

${ }^{10}$ The Third Report on the Law of Treaties, op. cit., 58

${ }^{11}$ The Yearbook of the International Law Commission, 1/1964, 283, paras 11, 13

${ }^{12}$ Ibid., 284, para 22

${ }^{13}$ Report of the International Law Commission on the work of its eighteenth session, Geneva, op.cit, 220 , para 10

${ }^{14}$ Ibid.

${ }^{15}$ The Third Report on the Law of Treaties, op.cit., 2/1964, 52
} 
in the Third part of the Draft devoted to application, effects, revision and interpretation of treaties.

The ILC considered the first version of the provisions, proposed by the Special Rapporteur, in May 1964. Discussion in the ILC resulted in the second version, consisted of Articles 69-73. ${ }^{16}$ Authentic and supplementary means of interpretation were separated in Articles 69 and $70 .{ }^{17}$ Under the name "General rule," Article 69 listed authentic means of interpretation. Article 70, under the title "Further means of interpretation" defined conditions for the use of supplementary means, their functions and referred to some of them. Article 71 was dedicated to terms having a special meaning. Articles 72 and $73^{18}$ addressed the differences which might appear between two or more authentic linguistic versions. Article 73 of the first version on the relevance of legal development after the conclusion of a treaty for its interpretation was dislocated in Section II on the modification of treaties and appeared as Article 68 under the title "Modification of a treaty by a subsequent treaty, by subsequent practice or by customary law".

In the second version a substantial change happened concerning legal qualification of various means of interpretation. The first version distinguished just a few means as authentic means: ordinary meaning of terms and context, including rules of international law in force at the time of the conclusion of a treaty. Other means were treated as supplementary. Object, purposes, and subsequent practice were lifted among authentic means in the second version.

As redrafted these provisions in the second version were generally supported by States, but in 1966 in the light of the comments of States and in a process of fine-tuning of the Draft the ILC reduced these five Articles to the three and relocated them in new Part III under title "Observance, application and interpretation of treaties" and renumbered them in Articles 27-29.19 It was the last, third version. They got its final normative structure and content. The first two Articles are devoted to authentic and supplementary means of interpretation respectively, and the third fused Articles 72 and 73 of the second version on interpretation of treaties authenticated in two or more languages in Article 29. With very small changes ${ }^{20}$ they were adopted by the Vienna Conference and now make Articles 31-33 of the VCLT.

${ }^{16}$ This version, presented in the Report of the ILC, was preceded by a previous second version, prepared by the Special Rapporteur and published in The Yearbook of the International Law Commission, 1/1964, 309. Since differences between two texts are minimal, for the sake of simplicity, I refer to the version published in the Report of the ILC as the second version.

${ }^{17}$ Report of the International Law Commission covering the work of its sixteenth session, 11 May - 24 July 1964, A/5809, The Yearbook of the International Law Commission, 2/1964, 199

${ }^{18}$ Ibid., 206

${ }^{19}$ Report of the International Law Commission on the work of its eighteenth session, op.cit., 217.

${ }^{20}$ Article 27 (3 b) which stated: "Any subsequent practice in the application of the treaty which establishes the understanding of the parties regarding its interpretation" was reformulated 
International courts affirmed customary character of Articles 31 and 32 of the VCLT. ${ }^{21}$ Consequently, they apply the rules to international persons who are not the parties to the VCLT and to international treaties concluded before entrance in the force of the VCLT. ${ }^{22}$

In 2008 the ILC decided to include the issue "Treaties over time." In the framework of that topic the ILC has returned to further consideration of the two means of interpretation, subsequent agreements (Article 31 (3 a)) and subsequent practice (Articles 31, (3 b) and 32), and for the time being the Special Rapporteur, Georg Nolte has submitted three Reports ${ }^{23}$ and the ILC adopted eleven draft conclusions.

\section{TEXTUAL INTERPRETATION}

One of the reasons for codification of the provision on interpretation, stated by Sir $\mathrm{H}$. Waldock was that codification might be useful to stress "the significance of the text as the expression of the will of the parties." ${ }^{24}$ The proposal of fundamental rule in paragraph 1 of Article 70 in the first version was strongly inspired by textual approach: "The terms of a treaty shall be interpreted in good faith in

in Article 31 (3b) as follows: "any subsequent practice in the application of the treaty which establishes the agreement of the parties regarding its interpretation." Paragraph 3 of Article 29 - 'The terms of the treaty are presumed to have the same meaning in each authentic text. Except in the case mentioned in paragraph 1 , when a comparison of the texts discloses a difference of meaning which the application of articles 27 and 28 does not remove, a meaning which as far as possible reconciles the texts shall be adopted" - was divided in paragraphs 3 and 4 of Article 33 and reads: " 3 . The terms of the treaty are presumed to have the same meaning in each authentic text. 4.Except where a particular text prevails in accordance with paragraph 1, when a comparison of the authentic texts discloses a difference of meaning which the application of articles 31 and 32 does not remove, the meaning which best reconciles the texts, having regard to the object and purpose of the treaty, shall be adopted." The title of Article 29 - "Interpretation of treaties in two or more languages" - was supplemented by "authenticated" in Article 33 and reads "Interpretation of treaties authenticated in two or more languages."

${ }^{21}$ See the overview of judicial application of Articles $31-33$ of the VCLT by various international courts in the First report on subsequent agreements and subsequent practice in relation to treaty interpretation by Georg Nolte, Special Rapporteur, International Law Commission, Sixtyfifth session, Geneva, 6 May-7 June and 8 July-9 August 2013, A/CN.4/660, pp. 7-12.

22 Ibid.

${ }^{23}$ First report on subsequent agreements and subsequent practice in relation to treaty interpretation, op. cit.; Second report on subsequent agreements and subsequent practice in relation to the interpretation of treaties by Georg Nolte, Special Rapporteur, International Law Commission Sixty-sixth session Geneva, 5 May-6 June and 7 July-8 August 2014, A/CN.4/671; Third report on subsequent agreements and subsequent practice in relation to the interpretation of treaties by Georg Nolte, Special Rapporteur, International Law Commission Sixty-seventh session Geneva, 4 May5 June and 6 July-7 August 2015, A/CN.4/683.

${ }^{24}$ The Third Report on the Law of Treaties, op.cit., 54, para 8. 
accordance with the natural and ordinary meaning to be given to each term - (a) in its context in the treaty and in the context of the treaty as a whole; and (b) in the context of the rules of international law in force at the time of the conclusion of the treaty." 25

At the first moment, Bartoš was very dissonant stressing the paramount importance of the autonomy of will of the parties and asserting that "what the parties had intended was more important than what they had actually said in the treaty." ${ }^{26}$ However, at the next session he changed his mind saying that "he personally preferred objective interpretation, because the will of the parties as objectively expressed in the text of a treaty (unless there was very clear evidence of an error in wording) was the best guarantee of respect for the treaty and the best safeguard of treaty relations between States. ${ }^{27}$ Such approach was supported by Verdross ${ }^{28}$ and by Rosenne who quoted the very strong critics by Sir E. Beckett who disapproved of looking at intention as a core method of interpretation:

"There is a complete unreality in the references to the supposed intention of the legislature in the interpretation of the statute when in fact it is almost certain that the point which has arisen is one which the legislature never thought of at all. This is even more so in the case of the interpretation of treaties. As a matter of experience it often occurs that the difference between the parties to the treaties arises out of something which the parties never thought of when the treaty was concluded and that, therefore, they had absolutely no common intention with regard to it. In other cases the parties may all along have had divergent intentions with regard to the actual question which is in dispute. Each party deliberately refrained from raising the matter, possible hoping that this point would not arise in practice, or possibly expecting that if it did the text which was agreed would produce the result which it desired." 29

Pal thought that the fundamental rule of interpretation was expressed in Article 70 of the first version, since the real meaning of a treaty can be discovered by considering intention of the parties as far as they succeeded in expressing it in the language of a treaty. ${ }^{30}$ However, Yasseen challenged the absolute supremacy of clarity of a text, since the clarity might be relative and apparent. ${ }^{31} \mathrm{He}$ advocated

${ }^{25}$ The Third Report on the Law of Treaties, op.cit., 52

${ }^{26}$ The Yearbook of the International Law Commission, 1/1964, 279.

${ }^{27}$ Ibid., 287, para 57

${ }^{28}$ Ibid., 287, para 61

${ }^{29}$ Annuaire de l'Institut de Droit International, Vol. 43, tome 1, (1950), p. 438. Quoted in The Yearbook of the International Law Commission, 1/1964, 289, para 93

${ }^{30}$ The Yearbook of the International Law Commission, 1/1964, 286, para 51

${ }^{31}$ Ibid., para 49 
a thesis that sometimes it was necessary to consult preparatory work and circumstances surrounding the conclusion of the treaty in order to estimate whether the text was really clear. ${ }^{32}$ The very fast commitment to textual approach in the first version was weakened in the second version.

\section{CONTEXT}

In the first version, paragraph 1 of the Article 70 of the Draft the Special Rapporteur differentiated two sorts of context - context of the term and context of a treaty as a whole. The difference was not of particular importance, but it has been visible in the definition of the context. The text and the preamble were defined from the beginning as elements of the context. Stressing the importance of annexes to a treaty, Tabibi suggested putting them on equal footing with the preamble. ${ }^{33}$ This was accepted in the second version. According to paragraph 1 of Article 71 of the Draft in the first version the context of a treaty as a whole was defined to include in addition to the treaty (including its preamble) - (a) any agreement arrived at between the parties as a condition of the conclusion of the treaty or as a basis for its interpretation; (b) any instrument or document annexed to the treaty; (c) any other instrument related to, and drawn up in connexion with the conclusion of, the treaty. ${ }^{34}$ Numbered documents were not seen necessarily as the integral part of a treaty. It is interesting that the Special Rapporteur explained that these documents serve two purposes: they are not only evidence of intent of the parties which serves to resolve an ambiguity and obscurity but, as the part of a context, they serve to help establishing natural and ordinary meaning of terms of a treaty. ${ }^{35} \mathrm{He}$ raised the issue whether an agreed statement or understanding as to the meaning of a provision of a treaty, which was reached before the conclusion of a treaty, should be classified as part of a context or as preparatory works? Referring to contrary answers of the World Court in the Conditions of Admission to Membership case, where the Court chose the latter option, and in Ambatielos case, where the Court opted for the first option, the Special Rapporteur proposed to the Commission also the first option. ${ }^{36}$

The second version simplified the proposal, now in paragraph 2 of Article 69: "The context of the treaty, for the purposes of its interpretation, shall be understood as comprising in addition to the treaty, including its preamble and annexes,

\footnotetext{
${ }^{32}$ Ibid., 313 para 56, 314, para 66

${ }^{33} \mathrm{Ibid}$., 312 para 44

${ }^{34}$ The Third Report on the Law of Treaties, op. cit., 52

${ }^{35}$ Ibid., 58

${ }^{36}$ Ibid.
} 
any agreement or instrument related to the treaty and reached or drawn up in connexion with its conclusion." 37

Some members of the ILC, Lachs, ${ }^{38}$ Tunkin $^{39}$ and Rosenne ${ }^{40}$ were of the opinion that unilateral instruments not accepted by other parties were not parts of the context. Yasseen thought that an instrument of ratification was irrelevant, ${ }^{41}$ but Bartoš reminded that ratification was sometimes used for declaring a reservation and, if it was accepted, it became a part of the instrument. ${ }^{42}$

In its 1966 commentary of the third version the ILC stated: "The principle on which this provision is based is that a unilateral document cannot be regarded as forming part of the 'context' within the meaning of article 27 unless not only it was made in connection with the conclusion of the treaty, but its relation to the treaty was accepted in the same manner by the other parties." ${ }^{43}$ Further, the Commission stated: "What is proposed in paragraph 2 is that, for purposes of interpreting the treaty, these categories of documents should not be treated as mere evidence to which recourse may be had for the purpose of resolving an ambiguity or obscurity, but as part of the context for the purpose of arriving at the ordinary meaning of the terms of the treaty." ${ }^{4}$ Again, the ILC attributed to the context functions of authentic and supplementary means of interpretation.

\section{RULES OF INTERNATIONAL LAW AND INTER-TEMPORAL LAW}

"The context of the rules of international law in force at the time of the conclusion of the treaty" was defined as an authentic means of interpretation in Article 70, paragraph 1 (b) of the first version. ${ }^{45}$ Article 73 of the same version required that the emergence of later customary rules affecting the subject-matter of the treaty binding upon all the parties, later agreement between all the parties relating to the subject matter and subsequent practice in relation to the treaty manifesting the

\footnotetext{
${ }^{37}$ Report of the International Law Commission covering the work of its sixteenth session, op.cit.,199

${ }^{38}$ The Yearbook of the International Law Commission, 1/1964, 285, para 44

${ }^{39}$ Ibid., 310 para 8

${ }^{40} \mathrm{Ibid}, 313$ paras 52,54

${ }^{41}$ Ibid, 313 para 49

${ }^{42}$ Ibid, 313 para 50

${ }^{43}$ Report of the International Law Commission on the work of its eighteenth session, op.cit., 221, para 13

${ }^{44}$ Ibid.

${ }^{45}$ The Third Report on the Law of Treaties, op.cit., 52
} 
consent of all parties to modification of the treaty, should be taken into account by the interpretation of a treaty. ${ }^{46}$ The two provisions opened the issue of inter-temporal law. According to the first provision, the rules of international law in time of the conclusion of a treaty were relevant for the interpretation. The second provision made legal development, occurred after the conclusion of a treaty and consisting of emergence of new relevant customary rules, new relevant agreement or subsequent practice in the application of a treaty, which modified the treaty, relevant for its interpretation.

The first difference among the members of the ILC was the issue whether rules or principles of international law are relevant for the interpretation of a treaty. Tunkin ${ }^{47}$ and $\mathrm{Ago}^{48}$ preferred principles of international law. The Special Rapporteur replied that he had used the term "the rules" rather than "the principles" to stress the importance of a specific context, which might be also a regional context consisted, for example, of the rules applicable in Latin America. ${ }^{49}$ De Luna supported such approach. ${ }^{50}$ Yasseen preferred keeping the term "the rules" and emphasized the importance of terms used in previous treaties. ${ }^{51}$ If the meaning of a term was established in previous treaties, the parties concluding a new treaty considered that the meaning of the term had been already given in previous treaties. ${ }^{52} \mathrm{He}$ explained that when concluding a treaty, the parties were expressing their intention having in mind factual and legal situation. ${ }^{53}$ So, the existing legal situation, created by the rules of international law in force at time of conclusion of a treaty, should be relevant for its interpretation. He thought also that interpretation required sometimes the reference to special rules which expressed certain concepts of international law. ${ }^{54}$ Verdross considered that rules of general international law could be important for interpretation and proposed the insertion of the word "general" between "the rules of" and "international law." 55 Sir H. Waldock asserted that regional international law and even local customs might be relevant for interpretation. ${ }^{56}$

Tunkin challenged inter-temporal determination in Article 70, paragraph 1 (b), alleging that rules of international law relevant for interpretation are those in

${ }^{46}$ Ibid., 53

${ }^{47}$ The Yearbook of the International Law Commission, 1/1964, 278, para 62, p. 310 paras 8, 9, p.316 para 16

${ }^{48}$ Ibid., 280, para 80, p., 310 paras 8, 9

${ }^{49}$ Ibid., 310 paras 8, 9

${ }^{50}$ Ibid., 310 para 13

${ }^{51}$ Ibid., 310 para 11

${ }^{52}$ Ibid., 310 para 11

${ }^{53} \mathrm{Ibid} ., 312$ para 28

${ }^{54}$ Ibid., 316 para 18

${ }^{55}$ Ibid., 316 para 12

${ }^{56}$ Ibid., 316 para 13 
force in time of interpretation, since there are some rules where States cannot contract out. ${ }^{57}$ Tunkin was of the opinion that the words "in force at the time of its conclusion" should be omitted. ${ }^{58}$ Later, Ago, Sir H. Waldock and De Luna advocated a thesis that the treaty itself resolved the inter-temporal dilemma. If it was not agreed otherwise, the presumption was that later legal evolution is of relevance for interpretation, since the States are obliged to obey to the international law in force. ${ }^{59}$ Ago said that changes of legal content of concepts like "territorial waters" or "territorial sea" affected the meaning of those terms in international treaties. ${ }^{60}$

Facing different views of members of the ILC as well as different comments of States, the ILC decided to omit inter-temporal reference, explaining "that, in any event, the relevance of rules of international law for the interpretation of treaties in any given case was dependent on the intentions of the parties, and that to attempt to formulate a rule covering comprehensively the temporal element would present difficulties. It further considered that correct application of the temporal element would normally be indicated by interpretation of the term in good faith. ${ }^{61}$

\section{GOOD FAITH}

Reference to good faith appeared in the first version. The Special Rapporteur said that the principle of good faith was flowing directly from the rule pacta sunt servanda. Application and certainly interpretation of a treaty in good faith is the substance of the rule, as it is defined by Article 26 of the VCLT. Besides, good faith is a legal basis of presumption that the text of a treaty is an expression of the intentions of the parties. The principle requires full compatibility between the intentions, the words and the acts.

\section{OBJECT, PURPOSES AND PREAMBLE}

Briggs proposed the rearrangement of the relationship between authentic and supplementary means of interpretation, as it was proposed in the first version, by advancing objects and purposes of a treaty in a class of primary means. ${ }^{62}$ Supporting Bartošs position that the spirit of a treaty should prevail over its words, ${ }^{63}$

${ }^{57}$ Ibid., 278, para 49

${ }^{58}$ Ibid., 310 para 8

${ }^{59}$ Ibid., 317 para 30

${ }^{60} \mathrm{Ibid}$., 316 para 27

${ }^{61}$ Report of the International Law Commission on the work of its eighteenth session, op.cit., 222, para 16

${ }^{62}$ The Yearbook of the International Law Commission, 1/1964, 275, para 12

${ }^{63}$ Ibid., 279, para 64, 68 
De Luna said that the objects and purposes of a treaty were the integral part of a treaty and that "all the intrinsic methods or interpretation should be exhausted before recourse was had to extrinsic methods." ${ }^{64}$ Due to this reason, he suggested that objects and purposes of a treaty should be mentioned in the definition of the context, as proposed by the Chairman Ago. ${ }^{65}$ It meant they should have been classified as primary means of interpretation. The Special Rapporteur and the Chairman agreed that objects and purposes of a treaty should be treated as primary means of interpretation and moved to paragraph 1 of Article $70 .{ }^{66}$ Bartoš proposed also lifting objects and purposes as elements of effective interpretation to Article $70 .{ }^{67} \mathrm{He}$ believed that the general rule in Article 70 should refer to objects and purposes of a treaty since they are of paramount importance for its interpretation. ${ }^{68}$ Lachs was of a similar view, considering that in the case of conflict between ordinary meaning of a term and objects and purposes the latter should prevail. ${ }^{69}$ Ruda $^{70}{ }^{70}$ osenne, ${ }^{71}$ Lachs $^{72}$ and Amado $^{73}$ stressed importance of the preamble of a treaty for its interpretation. ${ }^{74}$ So, in the second version, objects and purposes became authentic means of interpretation.

\section{TELEOLOGICAL INTERPRETATION}

Article 72 of the first version of the drafted provisions, under title Effective interpretation of the terms, expressed the principle ut res magis valeat quam pereat in the following way: In the application of articles 70 and 71 a term of a treaty shall be so interpreted as to give it the fullest weight and effect consistent - (a) with its natural and ordinary meaning and that of the other terms of the treaty; and (b) with the objects and purposes of the treaty. ${ }^{75}$ The principle should serve to provide the terms of a treaty with full effect of the intentions of the parties. It does not provide "extensive" or "liberal" interpretation that would go beyond what is expressed or necessarily implied in the terms of a treaty. ${ }^{76}$ The Special Rappor-

\footnotetext{
${ }^{64}$ Ibid., 281, para 85

${ }^{65}$ Ibid., 281, para 85

${ }^{66}$ Ibid., 281, paras 86-89

${ }^{67}$ Ibid., 288, para 76

${ }^{68}$ Ibid., 288, para 77

${ }^{69}$ Ibid., 289, para 87

${ }^{70}$ Ibid., 283, para 9

${ }^{71}$ Ibid., 283, para 16

${ }^{72}$ Ibid., 285, para 42

${ }^{73}$ Ibid., 286, para 55

${ }^{74}$ Ibid., 283, paras 9, 16, 285, para 42

75 The Third Report on the Law of Treaties, op.cit., 53

${ }^{76}$ Ibid., 60, para 27
} 
teur said that the principle might be seen as a requirement of good faith, but he invoked two reasons for its expression in a form of a special rule of interpretation. The first was that by implied terms in a treaty secure efficacy "to an intention necessarily to be inferred from the express provisions of the treaty." "The second was to indicate proper limits to the scope of implication of terms, so not to open the door for purely teleological interpretations. ${ }^{78}$ This is especially important in interpretation of constituent treaties of international organizations. ${ }^{79}$ Referring to the Reparation for Injuries Opinion, the Special Rapporteur noted that the International Court of Justice stressed that international personality of the Organization and its capacity to bring international claims "arose by necessary implication or necessary intendment from the terms of the Charter." 80 The proper limits are defined by intends a) and b) of Article 71: natural and ordinary meanings of terms in their context and object and purpose of a treaty. ${ }^{81}$ As a support for such limits the ILC invoked the following dictum from the Interpretation of Peace Treaties Advisory Opinion (I.C.J. Reports 1950, p. 229) and it said: "The principle of interpretation expressed in the maxim: ut res magis valeat quam pereat, often referred to as the rule of effectiveness, cannot justify the Court in attributing to the provisions for the settlement of disputes in the Peace Treaties a meaning which... would be contrary to their letter and spirit." 82 Sir H. Waldock concluded an explanation of Article 72 of the Draft by the following: This formulation, it is thought, while containing the principle of effectiveness within the four corners of the treaty, still leaves room for such measure of teleological interpretation as can legitimately be considered to fall within the legal boundaries of interpretation. ${ }^{83}$

Ruda was of the opinion that the maxim ut res magis valeat quam pereat did not require interpretation that would give the fullest weight and effect of a treaty, but interpretation that would take into account that all terms and provisions of a treaty had their reason and meaning in the text of a treaty. ${ }^{84}$ Concerning Article 72 members of the ILC agreed that the substance of the Article should be transplanted primary means of interpretation. ${ }^{85}$ The object and purposes were expressly stated as primary means and the principle $u t$ res magis valeat quam pereat was covered by the principle of good faith.

\footnotetext{
${ }^{77}$ Ibid., 61, para 29

${ }^{78}$ Ibid., 61, para 29

${ }^{79}$ Ibid., 61, para 29

${ }^{80}$ Ibid., 61, para 29

${ }^{81}$ Ibid., 61, para 30

${ }^{82}$ Report of the International Law Commission on the work of its eighteenth session, op.cit.,

${ }^{83}$ The Third Report on the Law of Treaties, op.cit., 61, para 30

${ }^{84}$ The Yearbook of the International Law Commission, 1/1964, 288-291 paras 95-98

${ }^{85}$ Ibid., 288-291 paras 69-120
} 219 , para 6 


\section{SUBSEQUENT PRACTICE}

Subsequent practice in the application of a treaty shows how the intention of the parties operates in the application of a treaty. ${ }^{86}$ Analyzing the practice of the World Court the Special Rapporteur concluded that subsequent practice should be regarded as a subsidiary means of interpretation. ${ }^{87}$ Equally as in the case of preparatory works, subsequent practice has a probative value if it reflects common understanding of the parties as to the meaning of terms. ${ }^{88}$ Still, according to the Special Rapporteur, practice of an individual party is of importance when it relates to an obligation of particular concern for that party. Probative value depends also on consistency of subsequent practice.

The Special Rapporteur analyzed relevance of practice of organs of international organizations in respect of interpretation of their constituent instruments. He was aware that in its Opinion on Certain Expenses of the United Nations the International Court of Justice used the subsequent practice of organs of the United Nations for some findings, but he stressed that this practice did not necessarily reflect the understanding of all state members, since minority might be outvoted. ${ }^{89}$ Further, the Special Rapporteur considered that subsequent practice is an authentic means of interpretation, if it is not only consistent and embraces all the parties and also if it is of such nature that indicates the understanding of the parties as reflecting an interpretation binding upon them..$^{90}$

Subsequent practice can be a gray field where the interpretation of a treaty overlaps with its amending. This happens, according to the Special Rapporteur, when subsequent practice reflects common interpretation of all parties that diverges from the natural and ordinary meanings of terms, as it was in the Temple case..$^{91}$ The Tribunal in arbitration between France and the United States regarding the interpretation of an Air Transport Service Agreement accepted that the Agreement was modified by the subsequent practice. ${ }^{92}$ The issue was further elaborated in Article 73 of the Draft where subsequent practice was exclusively an authentic means. ${ }^{93}$

During the discussion in the ILC the Special Rapporteur differentiated three modes of subsequent practice. Firstly, subsequent concordant practice of some parties to a general multilateral treaty might be evidence of proper interpretation. ${ }^{94}$ Secondly, subsequent concordant practice accepted by all the States concerned

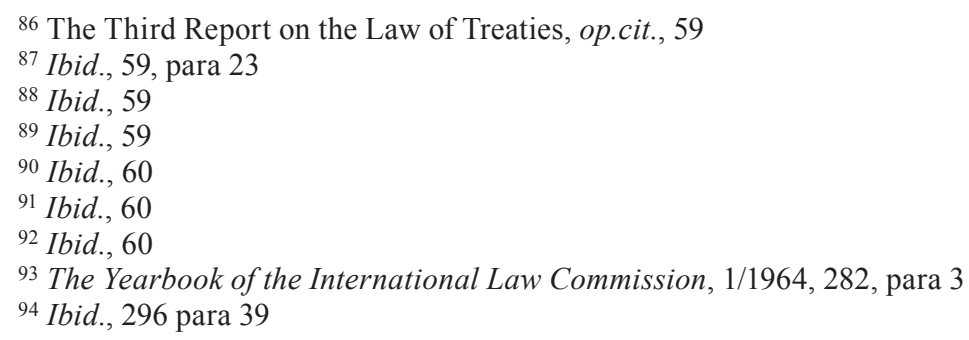


would be close to an authentic interpretation..$^{95}$ Thirdly, expressed in Article 73, was the case where subsequent practice could not be reconciled with the ordinary meaning of a treaty thought purporting to be an application of it. ${ }^{96} \mathrm{He}$ remarked that it might be difficult to make precise distinction between interpretation and modification by way of purporting interpretation. ${ }^{97} \mathrm{He}$ also asked the Commission how to treat subsequent practice, whether as subsidiary means of interpretation or as authentic means when the subsequent practice was concurrent practice of all parties to a treaty? ${ }^{98}$

De Luna advocated priority of subsequent practice to preparatory works. ${ }^{99}$ Chronologic order in the context of means of interpretation should not be decisive. The subsequent practice is more objective and certain. ${ }^{100}$ On the other hand, the subsequent practice might go beyond the interpretation towards modifying a treaty, since the parties are free to amend a treaty by their concurrent practice. ${ }^{101} \mathrm{Lachs}$ asked for a balance between subsequent practice and preparatory works, explaining that even those who had participated in preparatory works might change their minds later and express that change in their subsequent practice. ${ }^{102}$ The impression of the Chairman, Roberto Ago was that the Commission regarded subsequent practice more as an interpretative agreement than an aid to interpretation. ${ }^{103} \mathrm{He}$ said: "If the parties agreed to interpret a text in a certain way, that agreement prevailed; it was not merely a secondary means of clearing up an obscurity or resolving some other difficulty of interpretation." 104 The Special Rapporteur accepted that, but raised the issue of the subsequent practice of some parties to the treaty which was not disputed by the others. ${ }^{105} \mathrm{He}$ was of the opinion that silence was not conclusive and that this situation could not be equalized with the concurrent subsequent practice of all the parties to a treaty. ${ }^{106}$ Such subsequent practice would not be an authentic interpretation, but just an indication of the intention of the parties. ${ }^{107}$ He believed that such mode of subsequent practice might be covered by general reference to other means of interpretation as secondary sources. ${ }^{108}$ Having in mind other characteristics of subsequent practice, the Chairman Ago sorted it into

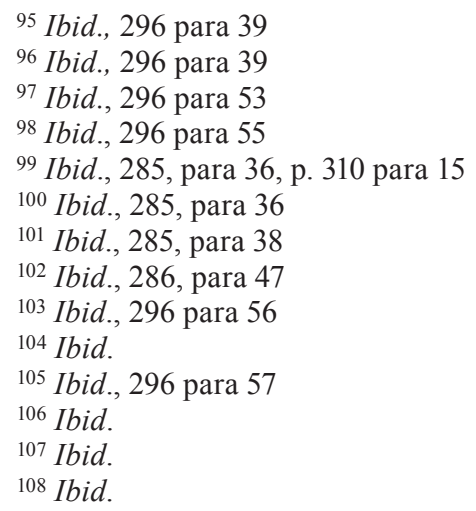


three categories. First, a practice which was not very definite was suitable to be an auxiliary element in interpretation. ${ }^{109}$ Second, a wholly concordant and definite practice was a sort of interpretative agreement. ${ }^{110}$ Third, practice that modified a treaty was equal to the amendment of a treaty. ${ }^{111}$

Following prevailing views in the ILC, the Special Rapporteur lifted subsequent practice among primary means of interpretation and offered the following formulation in paragraph 3 (b) of Article 69 in the second version: "Any subsequent practice in the application of the treaty which clearly establishes the understanding of all the parties regarding its interpretation." "112 However, he faced the problem of harmonization of the general rule on authentic means of interpretation in Article 69 of the second version and the subsequent practice. He also met the problem of the order of priority among the means numbered in Article 69. Additionally, he saw certain tension between the general rule and the subsequent practice. If ordinary meaning was clear, the subsequent practice, concordant to the ordinary meaning, it was just confirming the correct interpretation. ${ }^{113}$ But, in the case of doubts about the ordinary meaning, the subsequent practice might point to the correct interpretation. ${ }^{114}$ Even though he did not state this expressly, it seems that he thought that the subsequent practice should be a subsidiary means of interpretation. However, as the majority of the Commission wished to see it as a provision of Article 70, he located it there, but on the level under instruments or agreements ${ }^{115}$ and used the following formula familiar in English law to denote inferior position of subsequent practice: "Any subsequent practice ... shall also be taken into account (italic is mine) as if it formed part of the context of the treaty." 116

Concerning the participation of all parties in subsequent practice, in its commentary of 1966, the ILC gave the following interpretation: "The text provisionally adopted in 1964 spoke of a practice which 'establishes the understanding of all the parties'. By omitting the word 'all' the Commission did not intend to change the rule. It considered that the phrase 'the understanding of the parties' necessarily means 'the parties as a whole'. It omitted the word 'all' merely to avoid any possible misconception that every party must individually have engaged in the practice where it suffices that it should have accepted the practice."117

${ }^{109}$ Ibid., 296 para 58

${ }^{110}$ Ibid.

${ }^{111}$ Ibid.

112 Report of the International Law Commission covering the work of its sixteenth session, op.cit., 199

${ }^{113}$ The Yearbook of the International Law Commission, 1/1964, 309 para 4

${ }^{114}$ Ibid.

115 Ibid.

116 Ibid.

${ }^{117}$ Report of the International Law Commission on the work of its eighteenth session, op.cit., 222, para 15 
"Any relevant indications in the practice of individual parties" was under the level of the concordant practice of all parties. ${ }^{118}$ The Special Rapporteur saw the matter in the light of estoppel. ${ }^{119}$ By its practice of the application of a treaty, a party acknowledged interpretation reflected by the practice and the party was later estopped to evade such interpretation. Tunkin and the Special Rapporteur disputed about indications in the practice of individual parties. Tunkin recognized that the practice of individual parties might be taken into consideration, but he thought that such practice should not be on the same level as preparatory works and proposed the deletion of that part of the provision. ${ }^{120}$ Bartoš was in favor of the retention of the phrase, but he thought, like Tunkin that only common practice could be of relevance. ${ }^{121}$ Sir $\mathrm{H}$. Waldock opposed to deletion of the phrase and said that the practice of a number of States could be very important, especially in the case of multilateral treaties. ${ }^{122}$ Also, he proposed that the practice of individual parties could be referred to in the commentary as one of the other forms of evidence, without attributing special importance to it. ${ }^{123}$

Returning to the issue again in 2013 the ILC has extended further findings on subsequent practice which consists of conduct in the application of a treaty, after its conclusion. ${ }^{124}$ The "conduct" means any conduct attributable to a State in sense of the Draft Articles on State Responsibility. ${ }^{125}$ It includes acts, omissions and silence, which contribute to establishing agreement. ${ }^{126}$ The weight of a subsequent practice as a means of interpretation depends on its clarity, specificity and whether and how it is repeated. ${ }^{127}$ Criteria are defined in a non-exhaustive way. ${ }^{128}$ The ILC stated that fresh practice can replace old practice and that the replacement reflects a new common understanding of the parties regarding interpretation of a treaty. ${ }^{129}$

\section{PREPARATORY WORKS}

Sir H. Waldock made a distinction between preparatory works as a means of establishing meanings of terms (paragraph 2 of Article 70 of the first version)

${ }^{118}$ The Yearbook of the International Law Commission, 1/1964, 309 para 5

119 Ibid.

${ }^{120}$ Ibid., 314 para 72

${ }^{121}$ Ibid., 314 para 75

122 Ibid., 314 para 74

${ }^{123}$ Ibid., 314 para 76

${ }^{124}$ Report of the International Commission, Sixty-sixth session (5 May-6 June and 7 July - 8 August 2013), 31

${ }^{125}$ Ibid., 35, para 16

126 Ibid.

${ }^{127}$ Ibid., 192

${ }_{128}$ Ibid. 192, para. 2

${ }^{129}$ Ibid. 204, para 23 
and as a means of confirming meanings of terms, established as natural and ordinary meanings in the context (paragraph 2 of Article 71 of the first version). ${ }^{130}$ He admitted that the latter use of preparatory works was almost regular in practice of the World Court and other international judicial bodies and concluded: It would therefore be unrealistic to suggest, even by implication, that there is any actual bar upon mere reference to travaux préparatoires whenever the meaning of the terms is clear. ${ }^{131}$ Besides, he thought that some preparatory works might be treated as part of the context of a treaty as a whole, as mentioned above. ${ }^{132}$ The strength of preparatory works as evidence of intention of the parties depends on the extent to which they furnish proof of the common understanding of the parties as to the meaning of the terms of a treaty. Statements of individual parties during the negotiations are therefore of small value in the absence of evidence that they were assented to by the other parties. ${ }^{133}$

Concerning the multilateral treaties, he raised the issue whether preparatory works are relevant only for States which took part in the negotiations or for all parties if preparatory works have been published? ${ }^{134}$ In spite of the opposite position of the Permanent Court of International Justice in the River Oder Commission case, the Special Rapporteur was of the opinion that preparatory works should be of relevance for all parties, when they were published or unpublished, but accessible. ${ }^{135} \mathrm{He}$ explained that a state acceding to a treaty, in the drafting of which it did not participate, is entitled to ask to see preparatory works. ${ }^{136}$

Ruda and Rosenne criticized the use of preparatory works for confirmation of the meaning of term resulting from application of paragraph 1 of Article $70 .{ }^{137}$ De Luna referred to some weaknesses of preparatory works. Informal discussion in delicate phase of negotiations, which usually had not been noted in the records of negotiations, sometimes had decisive role in the conclusion of a treaty. ${ }^{138}$ Often, the parties placed on record as little as possible to escape unwished commitments in future. ${ }^{139}$ There is distinction between announced intentions and intentions actually carried out. ${ }^{140} \mathrm{Amado}$ rejected the treatment of the travaux préparatoires as an authentic interpretation by States, even if that interpretation modified the meaning of a treaty. ${ }^{141}$ Bartoš had also certain suspicions about the value of pre-

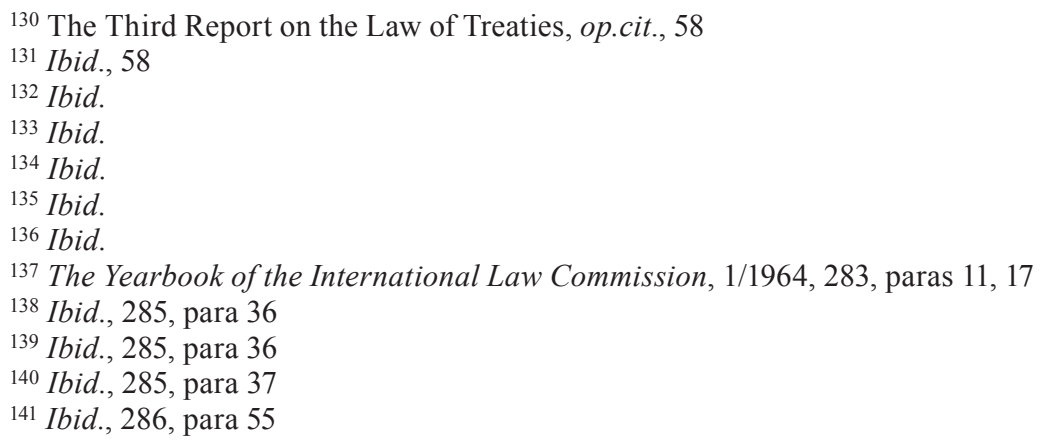


paratory works. He observed that the parties made conflicting declarations during negotiations and asked whether later acceding parties were obliged to know everything that had preceded the conclusion of a treaty. ${ }^{142}$ Sometimes, a compromise was reached at the last minute, which was not inserted in records and which departed from previous positions of the parties. ${ }^{143}$

\section{OPINIONS OF STATES REGARDING THE DRAFTED RULES ON INTERPRETATION}

The second version of the Draft was commented by States. Cyprus proposed giving more weight to that maxim ut res magis valeat quam pereat by express mention. ${ }^{144}$ Czech Government stressed the importance of textual approach and asked for reformulation of Article 69 by stating that the text is presumed to be the authentic expression of the intention of the parties. ${ }^{145}$ Israel also supported textual approach ${ }^{146}$ and understood that all elements of Article 69 were on an equal footing. ${ }^{147}$ Greece did not accept that priorities should have been established among various means of interpretation. ${ }^{148}$ Kenya considered that Articles $69-71$ presented a reasonable compromise of conflicting views. ${ }^{149}$

Hungary criticized the rigidity of textual approach in general rule, wishing that general rule clearly expressed that "it is the intention of the parties which is sought" and that is presumed that their intention appeared from the text. ${ }^{150}$ Portugal expressed a similar view. ${ }^{151}$ Further, Hungary believed that preparatory work was of the same importance as subsequent practice. ${ }^{152}$ Portugal was skeptical concerning inter-temporal determination in the reference to rules of international law in force at time of conclusion of a treaty, asserting that it was wrong especially in respect to law-making treaties. ${ }^{153}$

The Dutch Government agreed with the ILC concerning "the two basic principles adopted, namely that the actual text of the treaty is the most authorita-

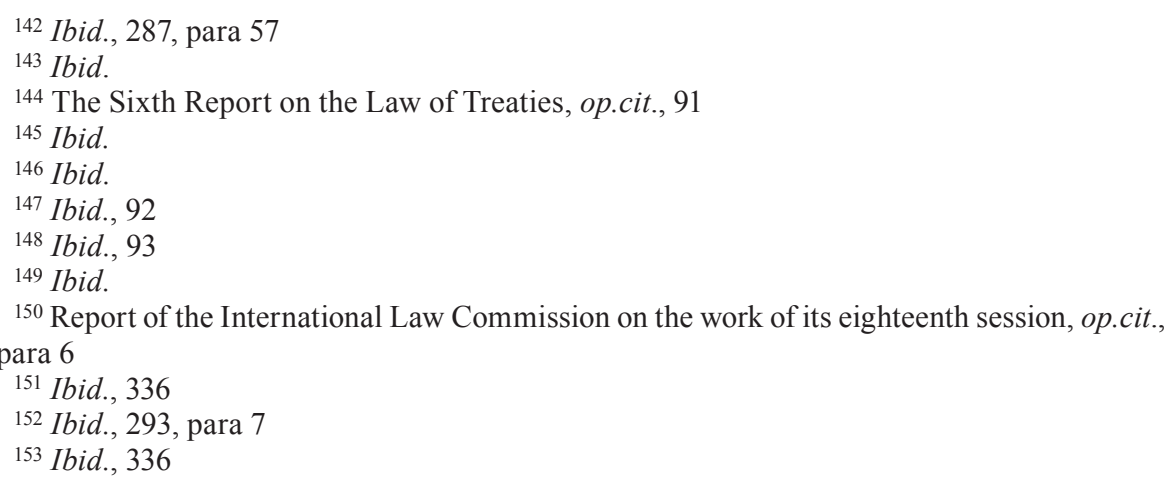


tive source from which to learn the parties' intentions, and that the text should be judged in the very first place in good faith. " ${ }^{\prime 54}$ Commenting the relationship in the general rule between reference to context of a treaty and objects and purposes, on one hand, and the reference to rules of international law on the other hand, the Netherlands asserted that those means of interpretation were not of equal value, that the reference to rules of international law was of less importance than the reference to context, objects and purposes and that the first means would not be applied if the second proved effective. ${ }^{155}$ The Netherlands also proposed that subsequent practice had the importance of authentic means of interpretation even without qualifier of common practice of all parties. ${ }^{156}$ Turkey emphasized that removing of difference in respect to rules on interpretation will strengthen the application of international treaties and supported the search for a consensus on the principles underlying these rules and on the order of their priority. ${ }^{157}$ It supported also relevance of rules of international law, as formulated by the ILC. ${ }^{158}$

The Great Britain supported the ILC approach that text of a treaty must be presumed to be the authentic expression of the intention of the parties. ${ }^{159}$ Syria emphasized the importance of general rules of international law, referred to by the ILC, in Article 69 for disclosing the wish of the parties. ${ }^{160}$

The USA asked whether other means of interpretation should also be enumerated and observed that the order in which the means of interpretation are stated has no significance respecting the relative weight of each of those means. ${ }^{161}$ But, impression of the USA was that the proposed provisions, as drafted, had given primacy to the ordinary meaning rule what would be a problem if the parties attributed by an agreement some special or technical meaning to a term. ${ }^{162}$ To avoid possible conflict, the USA proposed restructuring the general rule "by listing in paragraph 1 six rules of interpretation seriatim: (a) ordinary meaning; (b) context; (c) objects and purposes; (d) rules of international law; (e) agreement regarding interpretation; (f) subsequent practice in application."163 Concerning subsequent practice in the application of a treaty, the USA thought that action by one party which was not objected to by other parties would have appeared worthy

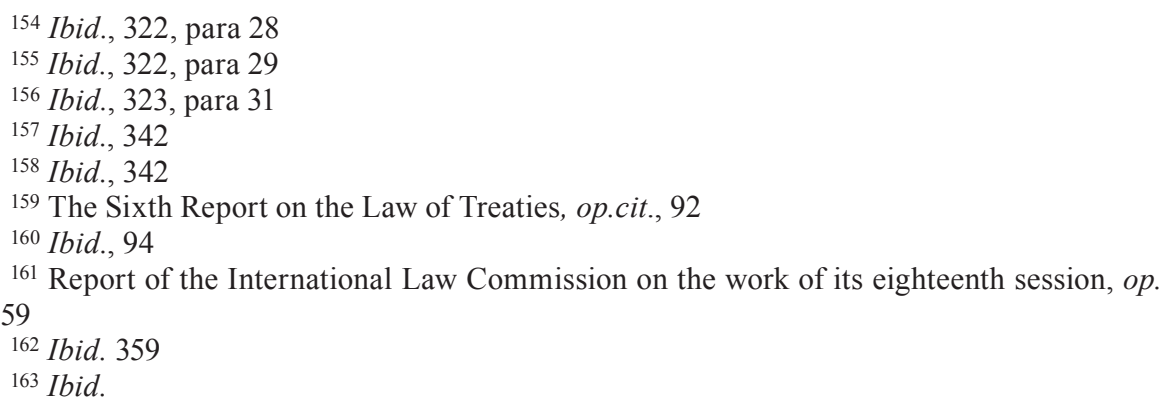


to be considered as a substantial guide to interpretation. ${ }^{164}$ Conditions for application of supplementary means were too restrictive, according to the opinion of this State, and in the case of a dispute on the meaning of a treaty provision, it suggested that recourse to other means of interpretation should be enabled. ${ }^{165}$

Yugoslavia considered that the proposed provisions should be extended by a special rule which would protect full effects of a treaty. ${ }^{166}$ It supported conditions foreseen for the application of supplementary means relating to preparatory work. ${ }^{167}$ Specially, Yugoslavia believed that the fact that States ordinary have in mind the actual text of a treaty and not preparatory work should be reflected in the provisions. ${ }^{168}$

\section{AUTHENTIC MEANS OF INTERPRETATION AND RELATIONSHIP AMONG THEM}

We have seen above that the list of authentic means of interpretation, proposed by the Special Rapporteur in the first version, was extended by the members of the ILC in later versions. In the end, in the third version general rule in Article $27^{169}$ (now Article 31) was composed of four paragraphs. Paragraph 1 informs how a treaty shall be interpreted. ${ }^{170}$ Paragraph 2 explains what makes the context for the purpose of interpretation. ${ }^{171}$ Paragraph 3 states what shall be taken into account together with context. ${ }^{172}$ Paragraph 4 is dedicated to the special meaning. ${ }^{173}$

Commenting the observations of States concerning the relationship among these means, the ILC stated: "Those observations appeared to indicate a possible

${ }^{164}$ Ibid.
${ }^{165}$ Ibid.
${ }^{166}$ Ibid., 361
${ }^{167}$ Ibid.
${ }^{168}$ Ibid.
${ }^{169}$ Ibid., 217

${ }^{170}$ Paragraph 1 reads: "A treaty shall be interpreted in good faith in accordance with the ordinary meaning to be given to the terms of the treaty in their context and in the light of its object and purpose."

${ }^{171}$ Paragraph 2 states: "The context for the purpose of the interpretation of a treaty shall comprise, in addition to the text, including its preamble and annexes: (a) Any agreement relating to the treaty which was made between all the parties in connexion with the conclusion of the treaty; (b) Any instrument which was made by one or more parties in connexion with the conclusion of the treaty and accepted by the other parties as an instrument related to the treaty."

172 Paragraph 3 is as follows: "There shall be taken into account, together with the context: (a) Any subsequent agreement between the parties regarding the interpretation of the treaty; (b) Any subsequent practice in the application of the treaty which establishes the understanding of the parties regarding its interpretation; (c) Any relevant rules of international law applicable in the relations between the parties."

${ }^{173}$ Paragraph 4 says: "A special meaning shall be given to a term if it is established that the parties so intended." 
fear that the successive paragraphs of article 27 might be taken as laying down a hierarchical order for the application of the various elements of interpretation in the article. The Commission, by heading the article "General rule of interpretation" in the singular and by underlining the connexion between paragraphs 1 and 2 and again between paragraph 3 and the two previous paragraphs, intended to indicate that the application of the means of interpretation in the article would be a single combined operation. All the various elements, as they were present in any given case, would be thrown into the crucible, and their interaction would give the legally relevant interpretation." 174 Further, the Commission explained: "...the word "context" in the opening phrase of paragraph 2 is designed to link all the elements of interpretation mentioned in this paragraph to the word "context" in the first paragraph and thereby incorporate them in the provision contained in that paragraph. Equally, the opening phrase of paragraph 3 "There shall be taken into account together with the context" is designed to incorporate in paragraph 1 the elements of interpretation set out in paragraph 3." 175

After examining the contemporary practice of the application of Articles 31 and 32 by various international courts in respect to various international treaties, the Special Rapporteur, Georg Nolte in his First Report proposed a conclusion that a treaty or a treaty provision may put a different emphasis on the various means of interpretation contained in Articles 31 and 32 of the VCLT, especially regarding the text of a treaty or its object and purposes. ${ }^{176}$ Starting from the proposal, the ILC adopted as point 5 in draft conclusion 1 the following formulation: "The interpretation of a treaty consists of a single combined operation, which places appropriate emphasis on the various means of interpretation indicated, respectively, in articles 31 and 32." 177 It is a step further from the1966 explanation of the ILC.

\section{SUPPLEMENTARY MEANS OF INTERPRETATION}

Paragraph 2 of Article 70 of the Draft in the first version regulated the relationship between authentic and supplementary means of interpretation: "If the natural and ordinary meaning of a term leads to an interpretation which is manifestly absurd or unreasonable in the context of the treaty as a whole, or if the

\footnotetext{
${ }^{174}$ Report of the International Law Commission on the work of its eighteenth session, op. cit., 219, para 8

${ }^{175}$ Ibid. 219, para 8

${ }^{176}$ First report on subsequent agreements and subsequent practice in relation to treaty interpretation, op. cit.. 13, para 28.

${ }^{177}$ Report of the International Law Commission, Sixty-seventh session, (4 May-5 June and 6 July-7 August 2015), New York, 2015, p. 86
} 
meaning of a term is not clear owing to its ambiguity or obscurity, the term shall be interpreted by reference to - (a) its context and the objects and purposes of the treaty; and (b) the other means of interpretation mentioned in article 71, paragraph 2." 178 Paragraph 2 of Article 71 stated: "Reference may be made to other evidence or indications of the intentions of the parties and, in particular, to the preparatory work of the treaty, the circumstances surrounding its conclusion and the subsequent practice of parties in relation to the treaty, for the purpose of - (a) confirming the meaning of a term resulting from the application of paragraph 1 of article 70; (b) determining the meaning of a term in the application of paragraph 2 of that article; (c) establishing the special meaning of a term in the application of paragraph 3 of that article."

The Special Rapporteur did not understand the two sorts of means as exclusive, since he qualified subsequent practice as supplementary means of interpretation that, under certain conditions, can be authentic means of interpretation. He also treated the contexts both as authentic and supplementary means. The Special Rapporteur was categorical in his position that supplementary means can be used only if the standard of ambiguity and obscurity was met; it is "where the text of the treaty itself was not sufficient to elucidate its meaning." 179 He wrote: "In these cases, and in these cases only, it is permissible to fix the meaning of the terms by reference to evidence or indications of the intentions of the parties outside the ordinary sense of their words." 180 The Special Rapporteur suggested that among various supplementary means of interpretation a preference should be given to the context of a term and object and purposes of a treaty. Subject to control of these means, the meaning of a term can be established by other evidence of intent of the parties in using the term. ${ }^{181}$ However, members of the ILC lifted these means among authentic means.

In the comment on the last version of the Draft, the ILC "pointed out that the provisions of article 28 by no means have the effect of drawing a rigid line between the 'supplementary' means of interpretation and the means included in article 27. The fact that article 28 admits recourse to the supplementary means for the purpose of 'confirming' the meaning resulting from the application of article 27 establishes a general link between the two articles and maintains the unity of the process of interpretation." 182

\footnotetext{
178 The Third Report on the Law of Treaties, op. cit., 52

${ }^{179}$ The Yearbook of the International Law Commission, 1/1964, 282, para 2

180 The Third Report on the Law of Treaties, op. cit., 57

181 Ibid.

${ }^{182}$ Report of the International Law Commission on the work of its eighteenth session, op.cit.,
} 220 , para 10 


\section{INTERNATIONAL JUDICIAL APPLICATION OF ARTICLES 31 - 33 OF THE VCLT}

The First report on subsequent agreements and subsequent practice in relation to treaty interpretation by Georg Nolte has shown two important matters. The international courts and tribunals recognize and apply Articles 31 and 32 of the VCLT, but differ in choosing available means of interpretation. ${ }^{183}$ The Appellate Body of the World Trade Organization has been concentrated on the text of a respective agreement. Occasionally, it has used evolutive interpretation or applied the principle of effectiveness, but did not particularly employed object and purpose as a means of interpretation. ${ }^{184}$ The Iran-United States Claims Tribunal has relied primarily on the ordinary meaning of terms and object and purpose. ${ }^{185}$ The interpretative practice of tribunals established by the International Centre for Settlement of Investment Disputes is not uniform, but does not attribute a special weight on the object and purpose nor on the presumed intentions of the parties. ${ }^{186}$ The European Court of Human Rights (hereinafter: the ECHR) prefers the principle of effectiveness and evolutive interpretation. ${ }^{187}$ The Inter-American Court of Human Rights has given priority to the object and purpose before ordinary meaning of terms. ${ }^{188}$ The European Court of Justice also has given priority to the object and purpose before the text. 189

That short summary of the review of application of Articles 31 and 32 by various international courts and tribunal, as well as the review as whole, presented in the First Report by Georg Nolte does not suffice. Interpretative practices of these bodies deserve comprehensive and detailed analysis. For example, the ECHR has become famous by considering the European Convention on Human Rights to be "a living instrument to be interpreted in light of present-day conditions." It repeated that Convention could not be interpreted solely in accordance with the intentions of their authors expressed more than forty years previously. ${ }^{190}$ Frequently, it uses

${ }^{183}$ See the overview of judicial application of Articles 31 - 33 of the VCLT by various international courts in the First report on subsequent agreements and subsequent practice in relation to treaty interpretation op.cit.,7-12.

${ }^{184}$ Ibid.. 7, para 11

${ }^{185}$ Ibid.. 7, para 12

${ }^{186} \mathrm{Ibid}$. 8, para 13. See, however, S. Djajić, O ciljnom tumačenju međunarodnih ugovora o zaštiti stranih ulaganja: od preambule do preambule, Zbornik radova Pravnog fakulteta u Novom Sadu 2/2015, p. 577

${ }^{187}$ First report on subsequent agreements and subsequent practice in relation to treaty interpretation, op. cit. 9 , para 17

${ }^{188}$ Ibid., 10, para 19

${ }^{189}$ Ibid., 12, para 27

${ }^{190}$ Loizidou v. Turkey, judgment of 23 March 1995 (preliminary objections), Series A no. 310, para 71, Bankovic and all v. Belgium and all, judgment of 12 December 2001, para 64 
subsequent practice in the application of the European Convention of Human Rights as a vehicle of evolutive interpretation. ${ }^{191}$ If concordant practice concerning the disputed issue prevails among the parties, the European Court of Human Rights declares that European consensus has been achieved and interprets a provision according to such consensus. However, it is not always the case. The ECHR considers that moral sensitivity, historical and political factors and other reasons can justify an isolated position of a Party which departs from widespread consensus. ${ }^{192}$ Beside, in the Bankovic case, interpreting Article 1 of the European Convention on Human Rights and searching for the meaning of a term "jurisdiction" the ECTHR departed from the evolutive interpretation, explaining that "the scope of Article 1, at issue in the present case, is determinative of the very scope of the Contracting Parties' positive obligations and, as such, of the scope and reach of the entire Convention system of human rights' protection." 193 In that case the ECHR relied on the travaux préparatoires in its confirmatory function, what was not frequently used.

The First Nolte's Report informs that interpretative practice of tribunals established by the International Centre for Settlement of Investment Disputes is not uniform. But, it is more striking fact that interpretative practice of chambers of the International Criminal Tribunal for the Former Yugoslavia is not uniform.

The important issue is what are the causes and consequences of differences in choosing different means of interpretation which exist not only among various international courts and tribunal, but also in the framework of the same judicial body. The issue of relevance of legal characteristics of international treaties and their provisions for selection of appropriate means of interpretation was considered before the codification started, for example, by Q. Wright, ${ }^{194}$ it was touched upon by the Special Rapporteur and members of the ILC during the process of codification 1964-1968, addressed by draft conclusion 1, point 5 of the ILC in 2013. It is alive and important issue. But, the tentative answer that legal characteristics of a treaty or a treaty provision are important for selection of the means of interpretation would not be a complete explanation of differences existing in interpretative practices concerning selection of means of interpretation. Since various judicial bodies interpret differently the same provision of a treaty. They apply the same rules of interpretation to the same provision of an international treaty and come

${ }^{191}$ R. Etinski, Subsequent Practice in the Application of the Convention for the Protection of Human Rights and Fundamental Freedoms as a Means of its Interpretation, Harmonization of Serbian and Hungarian Law with the European Union Law, Thematic Collection of Papers, vol. III, Novi Sad, 2015, 17 - 35

${ }^{192}$ K. Dzehtsiarou, European Consensus and the Evolutive Interpretation of the European Convention on Human Rights, German Law Journal 12/2011, 1733

193 Bankovic, para 65.

${ }^{194}$ Q. Wright, The Interpretation of Multilateral Treaties, The American Journal of International Law, 1929, 99-101 
to different meanings. The legal characteristic of the provision or of the treaty cannot explain such difference. It must be that there are other reasons, maybe facts of the case, or others.

The other important issue is the issue of consequences of choosing different various means of interpretation. Whether it serves aequum et bonum and how it reflects on legal certainty and predictability are relevant issues.

\section{CONCLUSIONS}

Basic rules on the interpretation of international treaties have been codified in Articles 31-33 of the VCLT and transplanted among general customary rules. They were created as a compromise of all different views of members of the ILC and States. Being a compromise, it does not address precisely enough all relevant issues. Authentic means have been enumerated in an exhaustive way in Article 31. Their positions in three paragraphs of the Article, the order of their listing in paragraphs does not reflect their relative weight and priority in course of application. The ILC advised the use all of them so that their interaction produce legally relevant interpretation. In the 1966 Comment on the third version of the Draft, the ILC stated: "All the various elements, as they were present in any given case, would be thrown into the crucible, and their interaction would give the legally relevant interpretation". It is not very precise instruction for the case where various means of interpretation lead to different results and when these results cannot be reconciled. It left certain discretion to interpreters.

Article 32 determines the conditions which have to be satisfied for application of supplementary means. It also defines two functions of supplementary means. The first of them, confirmatory is at disposition of the interpreter when Article 31 leads to a clear meaning and serve for its confirmation. The other function of determination of the meaning is available only if the application of Article 31 does not result in clear meaning. The Article exemplary refers to the circumstances surrounding the conclusion of treaties and preparatory works as supplementary means. The ILC considered also that subsequent practice of certain characteristics and the context can play the role of supplementary means. But, the list is not exhaustive. As the member of the ILC Rosenne expressed some doubts about confirmatory function of the preparatory works, considering that it might be just a mask of determinative function.

The international judicial practice of application of these rules show that the advice of the ILC that an interpreter should use all authentic means so that interaction among them leads to correct interpretation was not accepted by international judicial bodies. Usually, they use more, but not all available authentic means and usually they attached a special weight to some of them. It implies important 
issue of causes and consequences of such interpretative practice. The attributing different importance to various means of interpretation might be opportune if serves aequum et bonum. But, if it turns into ad-hocism, as it was named by an author, than it undermines the rule of law. Practitioners of international law would like to know what factors determine selection various available means of interpretation. If certain regularity might be discovered in that respect, it would be contribute to legal certainty, predictability and to the rule of law. 
Др Родољуб М. Еитински, редовни иррофесор

Универзииетеи у Новом Саду

Правни факулиетеи у Новом Саду

R.Etinski@pf.uns.ac.rs

\section{Средства тумачења и њихови међусобни односи}

Сажейак: Члановима 31 и 32 Бечке конвеничје о йраву међународних уг̄овора одређени су неки ауиеенииични и дойунски начини ииумачења међународних уг̃овора. Током ирроиеса кодификачије у Комисији за међународно ираво одређивање тиих начина није било ирредмети разлика између чланова Комисије или између држава, али одређивање реда ирриорииетиа међу њима јестеие било. На крају Комисија за међународно ираво је заузела стиав да сви ауиеенимични начини ииреба да буду иримењени и да ће юихова узајамна

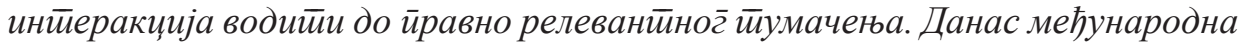

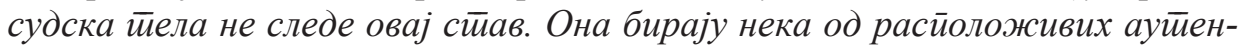

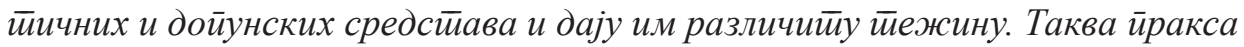
иуммачењ а може да служи аеqиит еt bопит, али може и да се изокрене у

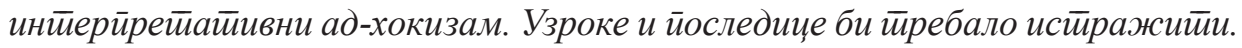

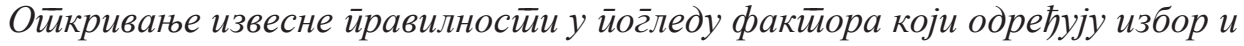
иежжиу различийих начина би мог̆ло да йовећа ираву извесности и ирред-

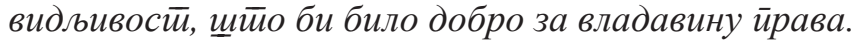

Кључне речи: йумачење, међународни уг̄овори.

Датум пријема рада: 30.04.2016. 